\title{
Spice Value Chain in Ethiopia: Scoping Review for Sustainable Management
}

\author{
Tewabe Hibistu \\ Department of Agricultural Economics, Debre Markos University, Ethiopia
}

\begin{abstract}
Diversifying crop in Ethiopia a long-standing production and price risk mitigation strategy employed by many farmers. Although spice production has paramount economic and non-economic multiple importance, its production is still showing shallow coverage and distribution in the country. Besides, the value chain is not as such exploiting the potential value addition and the number of participants to be embedded as chain actors is yet minimal. Spice value addition is shallowly undertaken ranging from the small-scale farmers production to the partial processing and this shows the conventional value chain being undertaken. Hence, much of the production coverage and the potential value addition in terms diversified processing should be taken up to boost the performance of spice sector in Ethiopia.
\end{abstract}

DOI: $10.7176 / \mathrm{JAAS} / 61-03$

Publication date: February $29^{\text {th }} 2020$

\section{Introduction}

In many parts of the world, agriculture continues to play a central role in economic development and to be a key contributor to poverty reduction. However, agriculture alone will not be sufficient to address the poverty and inequality that are so pervasive in today's world. It is becoming increasingly crucial for policy makers to focus immediate attention on agro-industries. One of these agro-industries is the spice sector. Such industries, established along efficient value chains, can increase significantly the rate and scope of industrial growth (EMI, 2015).

Value chain analysis is one of market resource management tools that are helpful to coordinate activities of all stakeholders in the sector. These days, value chain development became very popular as one of rural development approaches these days. If it is applied appropriately, vertical integration can make great contributions to bring farm products to the market, and it can promote agricultural commercialization along the value chain.

Ethiopia has suitable climate and different agro-ecology for the production of a variety of food crops. The major food crops grown are cereals, spices, pulses and oil seeds. A broad range of fruits and vegetables and cut flowers are among fast-growing export agro-products. Organic coffee, cotton, tobacco, sugar cane, tea, and spices are the main commercial cash crops grown in Ethiopia. The economy is agriculture based which accounts about $42.9 \%$ of the gross domestic product (GDP), $90 \%$ of foreign currency earnings, and $85 \%$ of employment. Generally, the overall economic growth of the country has been highly associated with the performance of the agriculture sector EIG (2015). According to EEA (2010), in a country like Ethiopia where the capital shortage is the bottleneck to the economic growth, enhancing production and export trade from agricultural sector is said to be the very important remedy.

Although spices provide multiple uses, the emphasis given by research and extension activities is very unsatisfactory (Tiru et al., 2017). Hence, a radical change should be undertaken in the system to exploit the benefit from these marginalized crops. This paper is, therefore, going to review spice production and marketing with a scope covering household level studies done before which will pinpoint future spice sector production and vale chain performance in the country.

\section{Spice Yield and Value Chain in Ethiopia}

\subsection{Spice Area Coverage and Productivity in Ethiopia}

The average spice production coverage in Ethiopia is around 222,700 hectares with average productivity of 244,000 tons per annum and estimated total potential coverage in the low land spice farming areas as 200,000 hectares (GIT, 2016). It is estimated that around 5 million smallholder farmers are involved in spice production. Spice yields are low, as cultivation practices are based on traditional knowledge that has been transferred from generation to generation. Smallholder farmers hardly use farming tools and inputs as pesticides, fertilizers and improved seeds. Moreover, the production system is mostly based on rain-fed agriculture, planning is poor, and farmers don't allocate suitable land for the cultivation of spices (Herms, 2015). The area under spices cultivation in Ethiopia varies annually and spatially. For example, it has been between 330,000 ha and 500,000 ha in the period 2005-2013. Total spice production increased from 238,000 million ton in 2005 to 418,000 million ton in 2013. Chillies, ginger, black cumin, black cardamom and turmeric were responsible for $97 \%$ of the national annual average spice production volume in the same period (Herms. 2015. In Ethiopia, the Southern National 
and Nationalities Peoples Regional States (SNNP), is the region which produces the maximum quantity of spices the country.

The data obtained from MoA (2013/14) indicated that the total production of spices in the three major producing regions of Amhara, Oromia and SNNP accounting for $15.5 \%$ \& $2 \%, 7.86 \% \& 11.4 \%$ and $76.1 \%$ \& $85.8 \%$ for the year $2011 / 12$ and $2012 / 13$ respectively. However, the total production of spices in 2012/13 decreases by $22 \%$ as compared to $2011 / 12$ production; SNNP region by $88 \%$ and Amhara region by $90 \%$.

As per the findings of Beemnet (2014), the potential uses of spice and aromatic plants that occur in Ethiopia in the preparation of the following products: Food flavoring and seasoning, Medicines (anti-oxidant, antiviral, germicidal and stimulant), Cosmetics, Insecticides, Beverages (alcoholic beverage and soft drinks) and Aromatherapy (massage and spa). Also, he added that spices are important export products, with a huge potential to transform farmers from producing merely for subsistence to a more market-oriented mode of production. The spice sub-sector has an immense potential for economic development and poverty reduction through creation and expansion of employment opportunities and distribution of income and foreign exchange earnings. However, despite all the potentials and opportunities, the spice sub-sector potential in Ethiopia has not been fully exploited and the sub-sector did not receive sufficient research and extension attention.

Despite being the homeland of many spice varieties, the production of spices in Ethiopia remains predominantly a small holder production activity. Small holder farmers carry out the production of spices largely as mixed production with other food and/or cash crops. Moreover, the spices sector in Ethiopia has multitudes of problems. Although Ethiopia is endowed with many spice varieties with diverse and multipurpose importance, the production and productivity are still facing a number of problems and challenges in a continual way. Most of the researcher argued that spices sector production in Ethiopia constrained mainly due to inadequate production input, shortage of access to credit, disease caused by fungi, lack of modern marketing system to properly guide the production, weak \& poor extension system and weak role of private commercial investors in spices production (Endrias and Asfaw, 2011, Fissiha, 2016, Habtewold et al., 2017, Mekdes et al., 2017). Farmers not aware about market requirements, the supply chain is too long, quality control and grading are entirely absent, there is no certification, there are no cooperatives, there are no research and extension services at all, and the marketing system is still very informal (MoA, 2013).

\subsection{Spice Value Chain in Ethiopia}

The spices supply process in Ethiopia involves a number of activities, that include: input supply, seed/variety selection, seed bed and transfer plot preparations, seed multiplication, land preparation, sowing/planting production, farm crop protection, weed and pest protection, harvesting, thrashing, semi/full drying and use of appropriate methods of drying, cleaning from foreign matters/mixture, proper packing and use of appropriate type of packing material, collection/bulking of the harvested spices, supplying, wholesaling, grinding/processing at milling facilities and also factories (including oleoresin preparations), retailing, and domestic consumption, and exporting to overseas markets (CSA, 2011).

Farmers from developing countries are not getting the right share of consumer price because of excessive margin mainly because of inefficient and costly transport. Besides transport problems, majorities of agricultural products in Ethiopia are small holder produces, and are not producing and selling their produce and agricultural inputs in an organized manner so that some of their benefit may transfer to the middlemen (Mekdes et al., 2017).

Furthermore, the value chains of developing country constraints to participation often are compounded by country-level challenges to competitiveness. As per Tiru et al (2017) these challenges begin from lack of awareness on spice production, processing, storage and marketing among producers. Farmers are still using their traditional farming practices and usually harvest very low yield. Similarly, the marketing system is not managed through organized efforts. Price of spices is not determined by the demand, supply and price information rather by individual decision. Individual decision making process of the marketing of spice leads to inefficient and ineffective service of the market. This implies farmers are not getting expected benefits from this sector. Weak regulatory institutions, inadequate transportation, power and water infrastructure and the absence of important upstream value chain actors, such as equipment, seed and fertilizer suppliers and firms providing supporting services are also challenges to be addressed (Hazell et al., 2010).

There is a shortage in supply for most spices in the world. Total production was estimated at 7.8 million ton per annum in 2013. The gap between increased demand, insufficient supply and speculation results in a steady increase of prices. For example, prices for spices imported to the EU from developing countries increased by $6.8 \%$ per year on average between 2010 and 2014. Because of its vast population and spicy food tradition, India is the largest producer and consumer of spices (Herms, 2015). Africa has a substantial role to play, and the continent is responsible for $12 \%$ of global spice production. African producers mainly focus on domestic and regional markets. Although Africa accounts for $12 \%$ of global production, the continent is only responsible for $6 \%$ of the volume imported into the EU. In contrast, Latin America and the Caribbean are responsible for $10 \%$ of EU-imported volume, while they account for $4 \%$ of global production. The major spice export countries in 
Africa are Nigeria, Ethiopia, Tanzania and Côte d'Ivoire, Uganda, Kenya and South Africa.

Ethiopia is a home land of many spices and a long history of spices trade, back to around 912 B.C. But in export terms, the current Ethiopian spice export trade was negligible, accounting for less than $1 \%$ of the country's total export earnings (Yimer, 2010). The subsector is still unsupported, low in productivity and inefficient, production remains predominantly a small holder production activity largely as mixed production with other food and/or cash crops and the export value was negligible (NTFP, 2013).

In 2010, the government of Ethiopia launched a Growth and Transformation Plan (GTP) which included the promotion of agro-industries. The GTP identifies the spice sector for potential development and aims to increase spice export revenue. However, value chain of spice in Ethiopia is generally characterized by; semi subsistence, low-input, low-productivity smallholder famers are seen as playing a crucial role in production process (Dessalegn, 2015).

Spice value chain in Ethiopia is resilient to external shocks and with that its ability to continue delivering a sustainable supply to meet demand. These were due to knowledge gap of the producers on plant management, absence of effective communication between actors in the chain, length of the chain, the inability to innovate, the concentration of market power and organization (Mathewos 2016).

Although many NTFP (non-timber forest products which includes spices here) are harvested for subsistence use and source of cash income for many rural households in Ethiopia, most commercial products are traded in local and roadside markets but a few products enter national and international markets. This situation couldn't assure reasonable profit of producers from their product (Bekele, 2011). Markets continue to be seen as the means for ensuring that smallholder producers of agricultural products are effectively integrated into the mainstream of national economies, especially in developing countries (Chilot et al., 2010). To the reverse, if market performance is inefficient, the sustainability of the production becomes questionable and as a result, a continuous supply of the commodity for the market becomes difficult (Nega et al., 2015).

Key actors in the spices value chain in Ethiopia include farmers and collectors at farm gate, input providers (seeds, fertilizer, packaging, transport), agents/brokers who act as an intermediate between collectors and European clients, traders who operate as principal, taking possession of the product and grinders (NABC, 2014).

Substantial body of works done on spice marketing and value chain show that it is flourishing, but many problems to yet to be addressed by the sector. For instance; the absence of inadequate innovate technologies, postharvest handling, irregular supply and variable quality of spices produced from forest and agricultural landscape, poor market and connecting roads infrastructure in major spice producing areas, lack of cash crop orientation towards high valued internationally traded crops (Herms, 2015; Desalegn, 2015; Fissiha, 2016; GIT, 2016; Mathewos, 2016).

Besides; weak role of private commercial investors in spices production, weak business linkage among stakeholders, limited use of improved agricultural technologies, the predominance of subsistence agriculture and absence of business oriented agricultural production system, unlicensed traders brokers in the trading of spices absence production and marketing based on enforceable quality standards, lack of value addition in terms of major agro processing activities in spices, price volatility due to changes in demand and supply in local and overseas markets and lack of organized market information service to the different actors in the spices are some of the marketing constraints of spices sector in Ethiopia.

\section{Conclusion and Policy Suggestion}

Spice production and productivity in the country is not fully maximized to the extent of the potential possible to reach while the value chain is not addressing multiple value addition options benefiting our farmers in the form of greater marketing margin.

Although the production of spice in Ethiopia is scattered and fairly low yield is gained, this sector is yet has the potential to outperform by improving the value chain that benefits much share to the farmers and adjustments to marketing procedures. Besides, supplying improved varieties of spice suiting different agro-ecologies and collaborations with nearby agricultural research institutes, cash-crop orientation trainings to farmers, and digging out ample spice processing options with establishment of factories is a huge marginal investment benefiting all actors in the spice value chain of the country at large and accruing farmer specific benefit share from the sector. Specific policy interventions by this sub-sector are suggested here-below:

Improving road: Feeder roads used by smallholders to take their spice to the main spice collection centers and markets are somewhat poor. Thus, farmers face that much difficulty in transporting their spice from farm to markets and spice collection centers. Hence, feeder roads connecting spatially distributed spice production will boost the value chain development to a higher stage.

Price setting: Prices setting of most spice products in the area lifting to traders. This is due to asymmetry of market information between market actors. Specially the producers no chance to get first hand market information because of there is discontinuity or no networks in most areas. Establishing modern pricing system and spice pricing strategies per season will also be a marginal development for this sub-sector. 
Training: Extension services have been significantly failed and led to cut in surplus production of spice in the country. This is because most of the extension system in the country is not production and value chain oriented lacking theoretical and practical scenarios in the field. Establishing a well-developed spice value chain will contribute its own share for the general sustainable development of the country. So, the extension system has to be redesigned in such a way that government agencies, agricultural development and agricultural research organizations, NGOs, farmers', traders' and processor associations to be fully aware of the changing relationships between markets, value chain and all the different actors in agriculture, and shape their policies and program accordingly.

\section{References}

Beemnet Mengesha. (2014). Herbs and Aromatic Plants in Ethiopia: Some Tips. In: Report of the Third Spices, Aromatic and Herbal Plants Subsector Stakeholders Platform Workshop held in Addis Ababa on January 23, pp. 57-61.

Bekele M. (2011). Forest plantations and woodlots in Ethiopia. Nairobi, Kenya: African Forest Forum.

Chilot, Y., Shahidur, R., Befekadu, B., \& Solomon, L. (2010). Pulses Value Chain Potential in Ethiopia: Constraints and opportunities for enhancing exports. International Food Policy Research Institute (IFPRI)

CSA (Central Statistical Agency) (2011). Large and Medium Scale Commercial Farms Sample Survey 2010/11 (2000 E.C.). Results at Country and Regional Levels: Report on Area and Production of Crops, and Farm Management Practices. Statistical Bulletin 505, Vol. VIII, Addis Ababa. Ethiopia.

Dessalegn Gachena. (2015). Analysis of Factors Determining the Supply of Ethiopian Cardamom Spice (Aframomum corrorima): A Case from Bench Maji Zone of SNNPR, Ethiopia. European Journal of Business and Management, 7(1).

EIA (Ethiopian Investment Agency). (2010). Investment opportunity profile for spice processing in Ethiopia. http://www.eap.gov.et/sites/default/files.

EMI (Ethiopian Ministry of Industry), 2015). Spice Industry Strategic Plan; 2015-2025, Ethiopia.

Endrias Geta and Asfaw Kifle (2011). Production, processing and marketing of ginger in Southern Ethiopia. Journal of Horticulture and Forestry,3(7): pp.207-213.

Ethiopia Investment Guide. (2015). Business opportunities for horticulture. http://ethioinvest.net/investmentopportunities/strategic-sectors/horticulture

Fissiha gebreyesus gebreazgaabher (2016). Determination of important factors affecting Production and marketing of korarima (aframomum Corrorima (braun) p.c.m. jansen) in western Ethiopia International journal of engineering development and research, 4(2):

GIT (Gatefarms International Trade). (2016). Ethiopian spices \& market potentials, Sebeta, Ethiopia. Habtewold Kifelew, Demes Fikere, Tewodros Luleseged, Dejene Bekele, Haimanot Mitiku and Wakjira

Habtewold Kifelew, Demes Fikere, Tewodros Luleseged, Dejene Bekele, Haimanot Mitiku and Wakjira Getachew. (2017). Seed spices production guideline. Ethiopian institute of agricultural research Addis Ababa, Ethiopia.

Hazell, Peter, Colin Poulton, Steve Wiggins, and Andrew Dorward. (2010). "The Future of Small Farms: Trajectories and Policy Priorities." World Development, 38(10): 1349-1361.

Mathewos Agize. 2016. Spice and Medicinal Plants Production and Value Chain Analysis from South-West Ethiopia. Journal of Pharmacy and Alternative Medicine. (www.iiste.org) Vol.10. ISSN 2222-4807 (online) ISSN 2222-5668.

Mekdes D, Teshale W, Getachew M. (2017). Value Chain Analysis of Red Pepper: The Case of Abeshge District, Guragie Zone, South Ethiopia. Int J Environ Sci Nat Res.; 2(3): 555590. DOI: 10.19080/IJESNR.2017.02.555590

MoANRMD (Ministry of Agriculture and Natural resources management directorate), (2013). Non-timber forest products development Training manuals series

NABC (Netherlands Africa Business Council) (2014). Factsheet: spices, herbs and aromatics in Ethiopia. https://www.nabc.nl/uploads/content/files/Factsheet\%20ABSF\%20spices, \%20herbs\%20and\%20aromatics. pdf.

Nega, M., Teshale, W., \& Zebene, A, (2015). Market Chain Analysis of Agro-forestry Products: The Case of Fruit at Tembaro District, Kembata Tembaro Zone South Ethiopia. International Journal of Business and Economics Research, 4(4), 201 216. https://doi.org/10.11648/j.ijber.20150404.13

NTFPs (None timber forest product), (2013), Development Training Manuals Serious, by ministery of agriculture in Ethiopia.

Tiru Tesfa, Wondimu Bayu, Arega Gashaw, Hassen Beshir. (2017). Spice Production, Marketing, and Utilization in South Wollo, Ethiopia. East African Journal of Sciences, 11(1): 27-36.

Yimer M. (2010). Market Profile on Spices: Ethiopia. Addis Ababa. Research paper submitted to UNCTAD ITC. 